\author{
(online) $=$ ISSN $2285-3642$ \\ ISSN-L = 2285- 3642 \\ Journal of Economic Development, Environment and People \\ Volume 4, Issue 2, 2015 \\ URL: http://jedep.spiruharet.ro \\ e-mail: office jedep@spiruharet.ro
}

\title{
The Importance of the Sustainability of Environmental Accounting
}

\author{
Habib Akdoğan ${ }^{1}$, Ela Hiçyorulmaz ${ }^{2}$ \\ ${ }^{1}$ Hitit University Faculty of Economics and Administrative Sciences, Corum, Turkey
}

\begin{abstract}
Rapid population growth, industrialization, unplanned urbanization, global warming, tourism activities and natural disasters have resulted in environmental issues that have reached global dimensions and started to threaten the life of creatures. For the permanent protection of ecological balance and sustainability, massive national and international regulations are needed. Threatening the life of creatures has not been considered in the system consisting of the establishment of equilibrium between man and nature as required. At this point businesses have important responsibilities. Businesses, for example, in order to prevent environmental pollution waste control systems, filtration systems, recycling methods etc. endured environmental costs in a variety of ways, as these costs are incurred also causes more businesses to see the value of protecting the environment.
\end{abstract}

The result of the activities of environmental impacts of enterprises can be considered, to be taken in the preparation of the necessary data to guide decisions, contacts and presentation of the stages of the environmental accounting system.

In this study, we first examine the concepts of environmental accounting, sustainability and environmental costs and then in the cement factories located in Turkey the environmental costs and environmental accounting will be given in the results of a survey made for the calculation of the sensitivity.

Keywords: Environmental Accounting; Sustainability; Environmental Costs

\section{JEL Codes: $M$}

\section{Entrance}

Nowadays, both developed and developing nations are faced with environmental problems. Environmental problems are not just for today's people and, countries but even pose a threat to future generations. Therefore, global warming, industrialization, excessive consumption of natural resources, environmental pollution factors must be addressed as a whole. To leave a liveable world to future generations, it is necessary to ensure sustainability. When we talk of sustainable development, only environmental sustainability comes to mind. However, in order to ensure sustainability; the nature and

This article was presented as a paper in International Conference on Economic Sciences and Business Administration (24-25 Oct. 2014) in Bucharest Romania.

${ }^{1}$ Corresponding author. Tel: +900364 22577 00, Fax: +90 03642257700

E-mail address: habibakdogan@hitit.edu.tr 


\author{
(online) $=$ ISSN $2285-3642$ \\ ISSN-L = 2285-3642 \\ Journal of Economic Development, Environment and People \\ Volume 4, Issue 2, 2015 \\ URL: $\underline{\text { http://jedep.spiruharet.ro }}$ \\ e-mail: office jedep@spiruharet.ro
}

level of goods and services, produced and used by a society, employer's perception, poverty and sensitivity to the environment must be dealt with together. Here is sustainability; we can conclude that linked with environmental concerns in broader competitiveness and employment concerns (Ashford \&Caldart, 2008:1044). Therefore, economic and ecological balance are considered as a whole and for the welfare of people, increasing levels of social, economic and cultural sustainability must be provided together.

In the 1960s, the first studies related to the environment in terms of accounting began, then in the 1980s, was considered as a separate title (Korukoğlu, 2011:81). Today, the environmental protection work is done beyond just a fad. The increasing damage to the environment, along with the environmental protection work has become a necessity. Together with an understanding of the dynamics of environmentalism, businesses also began to assume their responsibilities. How business uses of the environment or how much damage given to the environment, is of great importance in terms of strategies to be implemented. Environmental costs of documenting, reporting and controlling, including issues of environmental accounting as an accounting branch has been developed.

The implementation of environmental accounting of the monetary value of the environmental information needs to be determined. Today, only a fiscal nature in accounting system which processes are recorded and apart from the remaining operations cannot be recorded (Kırlığlu \&Can, 1998:103). However, at this point international financial reporting standards (IFRS's) not only emphasize the necessity of non-financial information to be also reported. This development is a big step in terms of environmental accounting. It is difficult to apply, the nature of non-financial reporting in terms of the application of environmental accounting. However, the basic concepts of accounting system taken from the concept of social responsibility (carrying financial and non-financial qualifications) must be reported to the appropriate people. When the information of the non-financial qualifications is ignored, this system constitutes a short fall of missing information.

\title{
2. Literature Summary
}

It is seen that a lot of scientific studies about environmental accounting, sustainability and environmental cost issues have been conducted. In this area there are many definitions have been made in environmental accounting. Some of these include;

All activities of a business to be classified as environmental, inventory holding, monitoring of changes in inventory, monetary or physical size of these changes is to provided and in addition, by integrating them with business balance sheet, the actual profitability of the business in the direction of the regulations are to be introduced (TUSIAD, 2005:25).In another definition; green accounting represents 'a process of identification, calculation, control, analysis and reporting of the costs generated by the enterpriseenvironment relationship, resulting from the prevention, the limitation and the elimination of the effects of ecological disasters with a favourable impact over the company and the environment (Vasile, 2008:1387). In yet another definition; operating costs related to the environment in the process of keeping them under control, whether in business activities of environmental expenditures, how much carbon and gas emissions resulting from the activities of that operation, activities that may be causing air pollution, or such as of the stages in the process of ensuring an effective environmental protection, must be reflected in the financial statements is defined (Bezirci transferred from Crawford et al., 2011:64). 


\author{
(online) $=$ ISSN $2285-3642$ \\ ISSN-L = 2285-3642 \\ Journal of Economic Development, Environment and People \\ Volume 4, Issue 2, 2015 \\ URL: $\underline{\text { http://jedep.spiruharet.ro }}$ \\ e-mail: office jedep@spiruharet.ro
}

Considering the definitions above regarding environmental accounting, environmental costs that occur during activities of enterprises, showing financial statements the relevant persons and institutions come to the forefront is to be presented in the form of reports.

The concept of sustainability has gained importance after the inclusion in the United Nations Brundtland Commission's report, in 1987. According to the definition of sustainable development contained in the report; preserving the ability to meet the needs of future generations, is to meet the needs of the present generation. (Yanık\&Türker, 2012:292).

According to Başkaya (2001:213) sustainable development model is founded on three basics. These are;

1. Consists of the current growth is unsustainable,

2. By meeting the needs of today, attaining a minimum level of prosperity of all people and the eradication of poverty,

3. Also life and welfare of future generations to secure work and during these studies, the pressure on the environment, is to keep a level that will not threaten civilization.

When examining this matter of implementation of the concept of sustainability seems to be quite difficult. Therefore in 1992, at the environmental development conference held in Rio de Janeiro along with other unnamed meetings after the Rio Summit sustainability was evaluated as global.

The concept of environmental costs, to sustain the activities of enterprises in the name of protecting the environment is considered as one of the folded costs (Melek\&Ozbirecikli, 2002:84). According to another definition, as a result of the business's production process, environmental quality affects negatively to reduce the cost (Graff \& the others, 1998:4) Therefore according to the environmental costs they arise as;

1. Prevention Costs

2. Use Costs

3. Loss Costs are divided into three main groups.

So far, environmental costs and environmental accounting issues have remained at the level of literature, what is happening in practice has not been studied very much. As a result, businesses, that is working towards protecting the environment and how that reporting is an issue of concern. In this study that was conducted on examining the situation in cement factories, determining their attitudes towards environmental accounting and environmental accounting in order to reveal the importance of the sustainability. 


\author{
(online) $=$ ISSN $2285-3642$ \\ ISSN-L = 2285 - 3642 \\ Journal of Economic Development, Environment and People \\ Volume 4, Issue 2, 2015 \\ URL: http://jedep.spiruharet.ro \\ e-mail: office jedep@spiruharet.ro
}

\title{
3. This is a Research about Evaluation of Sustainability of Environmental Accounting in Cement Factories
}

\subsection{Research Objectives}

The purpose of the study is the approaches by cement factories operating in Turkey to the environmental problems and to evaluate the sustainability of environmental accounting. In order to reach the goal of the study was established two hypotheses. They are as follows;

1-There is no relationship between environmental problems and the causes of environmental problems.

2-There is no relationship between the activity durations in the cements factories with environmental accounting and sustainability.

\subsection{Research Methods}

In this study, the survey method was used. To the preparation of the survey questions relevant to literature and studies on this subject have been examined previously. The data collection survey questions used consists of three sections. In the first chapter an overview of cement factories, environment-related opinions in the second chapter, and the third section of the participants thought about the concept of environmental accounting are mentioned. With this survey we tried to form an idea about cement factories. In order to implement the survey, 25 cement factories which have continuously operated in Turkey were selected randomly.

Under the analysis of the data obtained from SPSS 21 software was used. Five-point Likert scale was used in the study. The answer to each item codes varies between 1, 00 and 5, 00. Respondents to each question of: absolutely agree, agree undecided, disagree, strongly disagree, selected one of the categories stating their opinions on the topic. The survey sample used in application was presented in the appendix.

\subsection{Reliability of Research}

The consistency of the statements contained in the survey and to what extent the scale used to reflect the problems that reliability was tested with SPSS 21 program. When carrying out this analysis alpha (Cronbach) method was used. In the third part of the survey there contained questions for the reliability analysis results in the following Table- 1 and Table- 2 is located.

Table-1 Reliability Statistics

\begin{tabular}{|c|c|}
\hline Cronbach's Alpha & N of Items \\
\hline, 853 & 23 \\
\hline
\end{tabular}

Table-2 Item-Total Statistics

\begin{tabular}{|l|c|c|c|c|}
\hline & $\begin{array}{c}\text { Scale Mean if Item } \\
\text { Deleted }\end{array}$ & $\begin{array}{c}\text { Scale Variance if Item } \\
\text { Deleted }\end{array}$ & $\begin{array}{c}\text { Corrected Item-Total } \\
\text { Correlation }\end{array}$ & $\begin{array}{c}\text { Cronbach's Alpha if } \\
\text { Item Deleted }\end{array}$ \\
\hline Question1 & 88,6800 & 109,893 &, 453 &, 848 \\
\hline Question2 & 88,6000 & 112,167 &, 339 &, 851 \\
\hline Question3 & 89,1200 & 106,693 &, 392 &, 848 \\
\hline
\end{tabular}


(online) $=$ ISSN $2285-3642$

ISSN-L = 2285 - 3642

Journal of Economic Development, Environment and People

Volume 4, Issue 2, 2015

URL: http://jedep.spiruharet.ro

e-mail: office jedep@spiruharet.ro

\begin{tabular}{|c|c|c|c|c|}
\hline Question4 & 89,4400 & 104,757 & ,369 & ,850 \\
\hline Question5 & 88,7200 & 109,960 & ,437 & ,848 \\
\hline Question6 & 89,2800 & 106,043 & ,357 & ,850 \\
\hline Question7 & 89,0400 & 102,873 & ,611 &, 840 \\
\hline Question8 & 89,2000 & 102,667 & ,497 & ,844 \\
\hline Question9 & 88,9200 & 107,660 & ,454 & ,847 \\
\hline Question10 & 88,8800 & 111,443 & ,235 & ,853 \\
\hline Question11 & 89,2000 & 103,917 &, 527 & ,843 \\
\hline Question13 & 88,5600 & 111,257 & ,472 & ,849 \\
\hline Question14 & 89,6400 & 106,990 & ,282 & ,854 \\
\hline Question15 & 89,9600 & 99,540 &, 572 & ,841 \\
\hline Question16 & 90,1600 & 99,140 &, 571 & ,841 \\
\hline Question17 & 89,4000 & 104,667 & ,493 &, 845 \\
\hline Question18 & 89,8400 & 103,890 & ,517 & ,844 \\
\hline Question19 & 89,7200 & 104,877 & ,527 & ,844 \\
\hline Question20 & 89,0800 & 109,743 & ,248 & ,853 \\
\hline Question21 & 90,6800 & 106,477 & ,326 &, 852 \\
\hline Question23 & 88,6800 & 109,310 &, 504 & ,847 \\
\hline Question24 & 89,4400 & 104,507 & ,490 &, 845 \\
\hline Question25 & 89,6800 & 108,060 & ,257 & ,854 \\
\hline
\end{tabular}

As a result of the analysis, contained in Table- 1 Cronbach's alpha the coefficient $=0,853$ respectively. Analysis of the obtained values of the scale shows that of a highly reliable. In Table-2 the results of reliability analysis for each question are located separately. Questions when evaluated separately in the analysis are seen to be highly reliable.

\subsection{Research Results and Evaluation}

Of the importance of sustainability in terms of environmental accounting for disclosing all the surveyed factories was answering the questions. The analysis results are as follows; cement factories surveyed, as long as it operates in Table-3 'are also shown.

Table-3 Cement Factories Operating Times

\begin{tabular}{|l|c|c|c|c|}
\hline \multicolumn{2}{|c|}{} & Frequency & Percent & Valid Percent \\
\hline \multirow{4}{*}{ Valid } & $0-10$ & 2 & 8,0 & 8,0 \\
\cline { 2 - 5 } & $11-20$ & 1 & 4,0 & 4,0 \\
\cline { 2 - 5 } & $21-30$ & 3 & 12,0 & 12,0 \\
\cline { 2 - 5 } & $31-40$ & 3 & 12,0 & 12,0 \\
\cline { 2 - 5 } & $40->$ & 16 & 64,0 & 64,0 \\
\hline
\end{tabular}




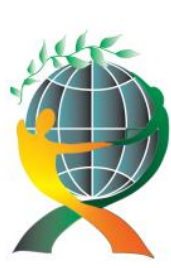

\author{
(online) $=$ ISSN $2285-3642$ \\ ISSN-L = $2285-3642$ \\ Journal of Economic Development, Environment and People \\ Volume 4, Issue 2, 2015
}

URL: http://jedep.spiruharet.ro

e-mail: office jedep@spiruharet.ro

\begin{tabular}{|c|c|c|c|c|}
\hline \multicolumn{2}{|c|}{} & Frequency & Percent & Valid Percent \\
\hline \multirow{6}{*}{ Valid } & $0-10$ & 2 & 8,0 & 8,0 \\
\cline { 2 - 5 } & $11-20$ & 1 & 4,0 & 4,0 \\
\cline { 2 - 5 } & $21-30$ & 3 & 12,0 & 12,0 \\
\cline { 2 - 5 } & $31-40$ & 3 & 12,0 & 12,0 \\
\cline { 2 - 5 } & $40->$ & 16 & 64,0 & 64,0 \\
\cline { 2 - 5 } & Total & 25 & 100,0 & 100,0 \\
\hline
\end{tabular}

Analysing Table-3, 64\% of surveyed cement factories have been operating for more than 40 years continuously. However, the average lifespan of business in turkey is 34 years (www.capital.com.tr). When viewed from this perspective, a large portion of the cement factories in Turkey, are above average activity time. The factory number, which operating time between 21-30 years and 31-40 years have equal zone of $12 \%$. The activities range from 11 to 20 years' time has the lowest zone (4\%). The $8 \%$ Zone shows up to 10 years duration of activity. Cement factories number established a new or in operation for a short time is quite low. Considering both the number and activity times required, cement factories have the importance of environmental awareness.

They have documentation of cement factories; TSE, ISO 9001, ISO 14001, CE, EC and were grouped as other. In Table 4, having these documents and certificates are given the percentages of cement factories.

Table-4 Cement Factories Owned Documents

\begin{tabular}{|c|c|}
\hline TSE & $\% 96,6$ \\
\hline ISO 9001 & $\% 92$ \\
\hline ISO 14001 & $\% 100$ \\
\hline CE & $\% 56$ \\
\hline EC & $\% 72$ \\
\hline Other & $\% 48$ \\
\hline
\end{tabular}

As a result of the research; in the world, known as the ISO 14001 environmental management system certification it is seen that the survey taken by all who attended the cement factories. Some of the objectives of ISO 14001; to improve environmental performance, reduce pollution and to take control starting from the source is to provide input materials and energy-saving. Therefore, business having ISO 14001 certification, said that environmentally sensitive policies apply. In addition, cement factories have rate of $96,6 \%$ TSE certificate, $92 \%$ of the ISO 9001 certificate, $56 \%$ of the CE and $72 \%$ have a certificate of EC. ISO 9001 certificate means a quality management system. This is a system that covers all stages and seeks continuous improvement for businesses from assembling, manufacturing, and marketing along with after-sales services. It could be called a kind of kaizen approach. The CE marking is not a quality mark. This sign of health and safety has been created in order to ensure the free movement of goods among the Member States of the EU. It means the product on which it has been affixed meets all the requirements of the related directive.EU countries considered to be sensitive to the environment, this document can be said to become even more important. The EC mark certificate of conformity is issued by quality and 


\author{
(online) $=$ ISSN $2285-3642$ \\ ISSN-L = 2285 - 3642 \\ Journal of Economic Development, Environment and People \\ Volume 4, Issue 2, 2015 \\ URL: http://jedep.spiruharet.ro \\ e-mail: office jedep@spiruharet.ro
}

environment committee. Considering Table-4, which have these documents it is seen that high rates for cement factories. Legal requirements and preferences to be more environmentally conscious businesses have provided this high rating. Also the surveyed factories have answered to other groups; TS 18001 (OHSAS) for occupational health and safety management systems, ISO 50001 energy management system, ISO 10002 management systems consist of customer satisfaction. Cement factories which have these documents percentage is $48 \%$.

Significance of the documents described above has been tested by Anova test. Table- 5 the results obtained in is located.

Table-5 Anova Test Results

\begin{tabular}{|c|c|c|c|c|c|c|}
\hline & & Sum of Squares & $\mathrm{df}$ & Mean Square & $\mathrm{F}$ & Sig. \\
\hline \multirow[t]{3}{*}{ TSE } & Between Groups & ,293 & 4 & ,073 & 2,200 & ,106 \\
\hline & Within Groups & ,667 & 20 & ,033 & & \\
\hline & Total & ,960 & 24 & & & \\
\hline \multirow[t]{3}{*}{ ISO 9001} & Between Groups & ,903 & 4 & ,226 & 4,813 & ,007 \\
\hline & Within Groups & ,937 & 20 & ,047 & & \\
\hline & Total & 1,840 & 24 & & & \\
\hline \multirow[t]{3}{*}{ CE } & Between Groups & ,577 & 4 & ,144 & ,516 & ,725 \\
\hline & Within Groups & 5,583 & 20 & ,279 & & \\
\hline & Total & 6,160 & 24 & & & \\
\hline \multirow[t]{3}{*}{ EC } & Between Groups & 1,373 & 4 & ,343 & 1,873 & ,155 \\
\hline & Within Groups & 3,667 & 20 & 183 & & \\
\hline & Total & 5,040 & 24 & & & \\
\hline \multirow[t]{3}{*}{ Diğer } & Between Groups & ,969 & 4 & ,242 & ,919 & ,472 \\
\hline & Within Groups & 5,271 & 20 & ,264 & & \\
\hline & Total & 6,240 & 24 & & & \\
\hline
\end{tabular}

Anova test results; have shown that sensitivity to the environment of cement factories are seen to be significant. ISO 14001 certification is received by all respondents who were excluded from the analysis.

In Table-6, SPSS 21 program tested with the Correlation Method 'Environmental Problems and Causes of Environmental Problems' is shown. The numeric 'sig. value' shows the level of significance. 


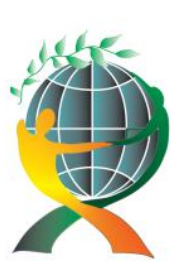

\author{
(online) = ISSN $2285-3642$ \\ ISSN-L = 2285- 3642 \\ Journal of Economic Development, Environment and People \\ Volume 4, Issue 2, 2015
}

URL: http://jedep.spiruharet.ro

e-mail: office jedep@spiruharet.ro

Table-6 Comparison of Environmental Issues and Causes of Environmental Problems

\begin{tabular}{|c|c|c|c|c|c|c|}
\hline & Air Pollution & $\begin{array}{c}\text { Water } \\
\text { Pollution }\end{array}$ & Soil Pollution & $\begin{array}{c}\text { Noise } \\
\text { Pollution }\end{array}$ & $\begin{array}{c}\text { Visual } \\
\text { Pollution }\end{array}$ & $\begin{array}{c}\text { Radioactive } \\
\text { Pollution }\end{array}$ \\
\hline $\begin{array}{c}\text { Population } \\
\text { Growth }\end{array}$ & 0,215 & 0,241 & 0,487 & 0,076 & 0,219 & 0,010 \\
\hline $\begin{array}{c}\text { Unplanned } \\
\text { Urbanization }\end{array}$ & 0,256 & 0,265 & 0,331 & 0,197 & 0,287 & 0,165 \\
\hline İndustrialization & 0,065 & 0,088 & 0,083 & 0,062 & 0,351 & 0,229 \\
\hline $\begin{array}{c}\text { Luxury Living } \\
\text { Standards }\end{array}$ & 0,210 & 0,244 & 0,205 & 0,490 & 0,343 & 0,411 \\
\hline $\begin{array}{l}\text { Climate } \\
\text { Changes }\end{array}$ & 0,577 & 0,603 & 0,253 & 0,298 & 0,314 & 0,230 \\
\hline Nuclear Tests & 0,295 & 0,374 & 0,151 & 0,223 & 0,147 & 0,150 \\
\hline Wars & 0,218 & 0,223 & 0,366 & 0,192 & 0,151 & 0,059 \\
\hline
\end{tabular}

Our first hypothesis established as 'there is no relationship between environmental problems and the causes of environmental problems' but the results of significance level of $5 \%$, which is shown above were that environmental problems and causes of environmental problems among have a relationship.

Examining Table-6, population growth has led to soil pollution the most. Because of increasing population, natural resources are becoming extinct, environmental quality decreases along with the quality of the soil, impaired for agricultural production practices (Mazı\& Tan, 2009:5). Unplanned urbanization problems have emerged due to, uncontrolled and unplanned growth of cities over rural areas. Due to unplanned urbanization, natural, historical and cultural structures are damaged. Therefore, soil pollution caused by urban sprawl is the most. Industrialization is expected to cause most of the water pollution. Because in our country, water pollution due to industry associations, liquid waste ranks first among the factors that are influenced (www.cevreonline.com).Luxury living standards are causing the most noise pollution. For example; such as people using private cars instead of choosing public transport, and noise is caused as a result of heavy traffic. Another ingredient contained in Table- 6 is climate change. According to the results climate change has led to most of the water pollution. However, in the second rating air pollution is very high. This revealed that the greenhouse gas effect is too large to be ignored as the results indicate. Nuclear test causes radioactive pollution on the air, water, and land. Therefore, the resulting values are close to each other. However, respondents stated that the most is water pollution caused by nuclear test. Our last items contained in Table-6 are from wars. According to the analysis result, war is the largest cause soil pollution.

In Table-7, below we find the activities of the cement factories and the environmental accounting concepts are evaluation with the 25 questions. 


\author{
(online) $=$ ISSN $2285-3642$ \\ ISSN-L = $2285-3642$ \\ Journal of Economic Development, Environment and People \\ Volume 4, Issue 2, 2015 \\ URL: http://jedep.spiruharet.ro \\ e-mail: office jedep@spiruharet.ro
}

Table-7 Comparison of Cement Factory Activity Durations and Environmental Accounting

\begin{tabular}{|c|c|c|c|c|}
\hline & Sum of Squares & Mean Square & $\mathrm{F}$ & Sig. \\
\hline Question1*Activity Durations & 1,773 & ,443 & 1,565 & ,222 \\
\hline Question2*Activity Durations & 1,060 & ,265 & 1,514 & ,236 \\
\hline Question3*Activity Durations & 6,977 & 1,744 & 2,239 & 101 \\
\hline Question4*Activity Durations & 6,236 & 1,559 & 1,053 & ,405 \\
\hline Question5*Activity Durations & 3,823 & ,956 & 4,854 & ,007 \\
\hline Question6*Activity Durations & 8,757 & 2,189 & 2,077 & 122 \\
\hline Question7*Activity Durations & 5,190 & 1,297 & 1,597 & ,214 \\
\hline Question8*Activity Durations & 6,277 & 1,569 & 1,251 & , 322 \\
\hline Question9*Activity Durations & 5,556 & 1,389 & 3,229 & ,034 \\
\hline Question $10^{*}$ Activity Durations & 5,469 & 1,367 & 4,039 & ,015 \\
\hline Question11*Activity Durations & 1,423 & ,356 & ,324 & ,858 \\
\hline Question12*Activity Durations & 7,523 & 1,881 & 1,278 & ,312 \\
\hline Question13*Activity Durations & 1,083 & 271 & 1,857 & 158 \\
\hline Question14*Activity Durations & 2,123 & ,531 & ,323 & ,860 \\
\hline Question15*Activity Durations & 2,833 & ,708 & ,403 & ,804 \\
\hline Question16*Activity Durations & 1,167 & ,292 & 150 & 961 \\
\hline Question17*Activity Durations & 1,356 & ,339 & ,314 & ,865 \\
\hline Question18*Activity Durations & 5,573 & 1,393 & 1,493 & ,242 \\
\hline Question19*Activity Durations & 1,343 & ,336 & ,365 & 831 \\
\hline Question20*Activity Durations & 1,769 & ,442 & ,459 & ,765 \\
\hline Question21*Activity Durations & 2,336 & ,584 & ,401 & ,805 \\
\hline Question22*Activity Durations & 2,269 & ,567 & 2,378 & 086 \\
\hline Question23*Activity Durations & ,607 & 152 & ,444 & ,775 \\
\hline
\end{tabular}




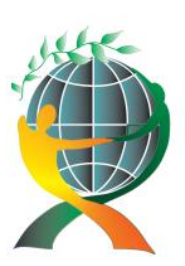

\author{
(online) = ISSN $2285-3642$ \\ ISSN-L = $2285-3642$ \\ Journal of Economic Development, Environment and People \\ Volume 4, Issue 2, 2015
}

URL: $\underline{\text { http://jedep.spiruharet.ro }}$

e-mail: office jedep@spiruharet.ro

\begin{tabular}{|l|c|c|c|c|}
\hline Question24*Activity Durations & 4,090 & 1,022 & 1,035 &, 413 \\
\hline Question25*Activity Durations & 7,0234 & 1,756 & 1,438 &, 258 \\
\hline
\end{tabular}

'There is no relationship between the activity durations in cement factories with environmental accounting and sustainability' was established as our second hypothesis; from the analysis results included in Table-7. As a result of the analysis of activity time, environmental accounting and sustainability issues have been shown to have effect. A difference could not be seen between a long time ongoing cement factories and a new cement factory operation. All the factories surveyed show the same care about the environmental sensitivity and the sustainability.

\title{
4. Result
}

A lot of health problems have emerged with natural habitat reduction and reached the global dimensions of environmental issues. This society should be more sensitive to the environment as an indicator. To protect the ecological balance and sustainability; businesses and consumers must act together; and permanent arrangements at national and international levels are necessary.

Businesses who prefer the concept of environmental management are replacing traditional businesses that continue its operations only for economic growth and profit. The purpose of environmentally sensitive business is to ensure sustainability and to improve the quality of life (Cetin, 2011:12). To ensure sustainability, economic, cultural and social considerations must be made together. The aspect of executed applications is not sufficient. Therefore, it is important for the concepts of unity and harmony.

In order to prevent environmental problems, from the accounting systems are also utilized. The concept of social responsibility in accordance with the basic concepts of accounting, business operations must be compatible with the natural environment. The cost of any damage to the environment should be a consideration. Older accounting systems ignored these environmental costs, environmental accounting systems are important. Because of environmental costs is \%20of the total costs (Ergin\&Okutmuş, 2007:154). This ratio must be considered. The purpose of environmental accounting is to establish a relationship between environment and economy, where environmental costs are ensured that the financial statements of the environmental accounting are examined.

Some of the countries use environmental accounting system in the world; Britain, Denmark, USA, Sweden and Japan. Environmentally sensitive businesses, especially in Japan, are more preferred. Therefore, depending on the Tokyo Stock Exchange from $80 \%$ in 1430, is applied to environmental accounting (TUSIAD, 2005:60).

In Turkey, a country rich in natural resources, businesses are becoming conscious of environmental issues. Especially cement plants acts more susceptible to environmental effects. However, environmental accounting system is a new concept in Turkey. Therefore, the study of the cement factories awareness of environmental accounting, information levels, environmental costs and opinions about sustainability were examined. According to research results the statement that; 'There are sufficient sources about the concept of environmental accounting'; a total of $80 \%$ strongly disagree, disagree and undecided answers are given. So $80 \%$ of the cement plants cannot find the resources. This ratio can benefit those businesses that do not have enough scientific resources in environmental accounting. Research on environmental 


\author{
(online) $=$ ISSN $2285-3642$ \\ ISSN-L = $2285-3642$ \\ Journal of Economic Development, Environment and People \\ Volume 4, Issue 2, 2015 \\ URL: $\underline{\text { http://jedep.spiruharet.ro }}$ \\ e-mail: office jedep@spiruharet.ro
}

accounting, academic level and implementation phase has led to these results remains weak. In this study, the expression with environmental awareness and environmental protection activities are examined, for cement factories, $76 \%$ strongly agree, $24 \%$ agree, giving an environmentally friendly policy in response was stated. In addition, for the cement factories; $92 \%$ allocated regular resources for environmental protection activities, $96 \%$ of these studies should be done for sustainability and $93 \%$ stated that they want to be environmental protection business. These rations, environmental accounting system to be implemented incomplete, does not show that cement plants are insensitive to the environment. Now with international financial reporting standards (IFRS) being, applicable at the international level treatment is more sensitive to environmental issues. For example, IFRS 41 standard implicitly drew attention to environmental costs. Standard net realizable value based on the valuation of biological assets and agricultural products to the identification guides. As seen, accounting standards takes into account the environmental costs. However, today, to be not taken into account in the accounting system standards, environmental protection costs incurred on behalf of, the investments are recorded at a different account groups and is offered to the person concerned. This information cannot provide sufficient information to users reporting. In addition, in cement plants, $80 \%$ strongly agree, $20 \%$ agree, giving the answer that worked for waste management and $96 \%$ for sustainability afforded to incur various costs stated. Along with the steady increase in the amount of waste, storage of these substances is constantly increasing the damage to the environment. Therefore, the businesses are acting more sensitive about waste management. Waste management provides, the reduction of carbon dioxide emissions, saving from fossil fuel and waste disposal completely, leaving little or no residue. Research in other statements an 'environmental accounting system for the development, Institutions and government agencies are required to cooperate with the relevant sectors' was in the form. When this statement analysed; $76 \%$ strongly agree, $24 \%$ agree was obtained. In line with these results, we can say that cement factories are ready and willing to cooperate to ensure the sustainability.

As a result of the survey, in Turkey for the implementation of environmental accounting system, the state and consumers as well as businesses need to act together to cooperate to create a result.

In this regard the following may be recommended;

- As consumers in Japan, eco-friendly businesses the choice of their products can make a big difference in terms of competition. Awareness of consumers to choose environmentally friendly products is provided with training form educational institutions. Therefore, students should be indoctrinated in awareness to prefer environmentally friendly products.

- Recycling should be an encouraged subject. Re-evaluation of waste, the tax refund method may be preferred.

- Creating incentives zones.

- Providing credit facility for investments.

- Supporting resource usage.

- Subsidies to enterprises that can provide ease of instituting environmental accounting.

- Environmental accounting can bring the legal obligation to affect.

By completing this phase of 'green business' businesses who deserves the title, they have achieved more comfortable in the market will compete with dignity. 


\author{
(online) = ISSN $2285-3642$ \\ ISSN-L = $2285-3642$ \\ Journal of Economic Development, Environment and People \\ Volume 4, Issue 2, 2015 \\ URL: $\underline{\text { http://jedep.spiruharet.ro }}$ \\ e-mail: office jedep@spiruharet.ro
}

\title{
5. References:
}

[1] ASHFORD, A.N. and CALDART, C.C., (2008). Environmental Law, Policy, and Economics: Reclaiming the Environmental Agenda, MIT Press, pp: 1043-1051

[2] BASKAYA, Fikret (2001). The Rise and Fall of Development Economics, ImgeBookstore, İstanbul ISBN: 9755330798

[3] BEZIRCI, Muhammet, OZPEYNIRCI, Rabia and DUMAN,Haluk(2011). "Sosyal Sorumluluk Kavramı Bağlamında Yeşil Muhasebe Eğitimi: Bir Alan Araştırması", Wolrd of Accounting Science, vol: 13, issue: 3, pp: 61-79.

[4] CETIN Eray, (2011). The Importance Production Businesses Pay to Green Accounting as a Social Responsibility: An Application on Production Businesses Running in Mersin-Tarsus Organized Industrial Zone, Master's thesis, Karamanoğlu Mehmetbey Univesity, Karaman-Turkey

[5] GRAFF, Robert, -REISKIN, Edward,D- WHITE, Allen,L- BIDWELL, Katherine. (1998). 'Snapshots of Environmental Cost Accounting', Tellus Institute, Environmental Accounting Project USEPA May 1998.

http://nepis.epa.gov/Exe/ZyNET.exe/200011B1.TXT?ZyActionD=ZyDocument\&Client=EPA\&Index=1995+Thru+1999\&D ocs $=\& Q$ uery $=\&$ Time $=\&$ EndTime $=\&$ SearchMethod $=1 \&$ TocRestrict $=n \& T o c=\&$ TocEntry $=\& Q$ Field $=\& Q$ Field Year $=\& Q F i e l d$ Month $=\& Q$ FieldDay=\&IntQFieldOp=0\&ExtQFieldOp=0\&XmlQuery=\&File=D\%3A\%5Czyfiles\%5CIndex\%20Data\%5C95thr u99\%5CTxt\%5C00000011\%5C200011B1.txt\&User=ANONYMOUS\&Password=anonymous\&SortMethod=h\%7C-

\&MaximumDocuments=1\&FuzzyDegree=0\&ImageQuality=r75g8/r75g8/x150y150g16/i425\&Display=p\%7Cf\&DefSeekP age $=x \&$ SearchBack=ZyActionL\&Back=ZyActionS\&BackDesc=Results\%20page\&MaximumPages=1\&ZyEntry=1\&SeekPag e=x\&ZyPURL(access date: 16.07 .2014 )

[6] KIRLIOĞLU, Hilmi and CAN, Ahmet Vecdi (1998). Environmental Accounting, DeğişimYayınları, Adapazarı

[7] KORUKOĞLU, Aysen (2011). Environmental Accounting in Business: Application of İzmir Province, Ege Academic Review, vol: 11, Issue: 1 pp: 81-89

[8] MAZI, Fikret and TAN, Mehmet (2009). Population Growth, Resource Exhaustion and Environment, Issue: 136, April. http://www.mevzuatdergisi.com/2009/04a/02.htm (access date: 14.07.2014)

[9] OZBIRECIKLI, Mehmet and MELEK, Zeynep (2002). Environmental Accounting Environmental Costs Impact on Cost Accounting System, Journal of Accounting and Finance (AAFA), Issue: 14

[10] TUSIAD June 2005 Report, 'Company of the New Management Tool: Environmental Accounting', no: TUSIAD$\mathrm{T} / 2005-06 / 404$

[11] VASILE, Patruţ; CRISTINA, Ciuraru - Andrica; MIHAELA, Luca (2008). Green Accounting- a Challenge for the Accountant Specialist, Annals of the University of Oradea, Economic Science Series; vol: 17, Issue: 3, p: 1387

[12] YANIK, Serhat and TURKER, Ipek (2012). Developments in Sustainability and Social Responsibility Reporting (Integrated Reporting), i.ü. Journal of the Faculty of Political Sciences, no: 47, pp: 291-308, October

[13] www.cevreonline.com/CevreKR/su\%20kirlilik\%20etmenleri (access date: 16.07.2014)

[14] www.capital.com.tr (access date: 16.07.2014)

[15] www.tse.org.tr (access date: 17.07.2014) 


\author{
(online) $=$ ISSN $2285-3642$ \\ ISSN-L = 2285 - 3642 \\ Journal of Economic Development, Environment and People \\ Volume 4, Issue 2, 2015 \\ URL: http://jedep.spiruharet.ro \\ e-mail: office jedep@spiruharet.ro
}

\title{
$\begin{array}{lll}\text { Appendix } 1 \text { SURVEY FORM } & \text { SU }\end{array}$
}

\section{SENSITIVITY OF CEMENT FACTORIES WITH ENVIRONMENTAL ACCOUNTING}

Mrs. Participant and Mr. Participant;

Businesses effects about environment has gained importance belong to environmental problems cannot be ignored. In this master's degree thesis we have been doing about sensitivity of cement factories with environmental accounting, we will be trying to evaluate. The information you provide will be used entirely for scientific purposes and will be treated according to the rules of scientific ethics. Thank you for the interest you have shown and the time you reserve in our research. We offer our respect.

Associate Professor Habib AKDOĞAN

Hitit University Faculty of Economics and Administrative Sciences, Corum, Turkey

Ela HiçYORULMAZ

Hitit University Institute of Social Sciences, Corum, Turkey

\section{General Information About to Business}

1.1. How many years has your business been operating?

\begin{tabular}{|l|l|l|l|l|}
\hline $1-10$ & $11-20$ & $21-30$ & $31-40$ & 41 and over \\
\hline & & & & \\
\hline
\end{tabular}

1.2. What is the number of staff employed in your business?

\begin{tabular}{|l|l|c|}
\hline $10-49$ & $50-249$ & 250 And Over \\
\hline & & \\
\hline
\end{tabular}

1.3. What are certificates that you have?

\begin{tabular}{|c|c|c|c|c|c|}
\hline TSE & ISO 9001 & ISO 14001 & CE & EC & THE OTHERS \\
\hline & & & & & \\
\hline
\end{tabular}

\section{Opinions About The Environment}

2.1. Cement Factory, the following please indicate the degree of environmental issues of importance to you.

\begin{tabular}{|l|l|l|l|l|l|}
\hline Environmental Issues & $\begin{array}{c}\text { Very } \\
\text { Unimportant }\end{array}$ & Unimportant & Undecided & Important & Very Important \\
\hline 1. Air Pollution & & & & & \\
\hline 2. Water Pollution & & & & & \\
\hline 3.Soil Pollution & & & & & \\
\hline 4.Noise Pollution & & & & & \\
\hline 5.Visual Pollution & & & & & \\
\hline 6.Radioactive Pollution & & & & & \\
\hline
\end{tabular}

2.2. The following causes of environmental problems please indicate the degree of importance to you.

\begin{tabular}{|l|c|c|c|c|c|}
\hline Causes of Environmental & Very & Unimportant & Undecided & Important & Very Important \\
\hline
\end{tabular}


(online) = ISSN $2285-3642$

ISSN-L = $2285-3642$

Journal of Economic Development, Environment and People

Volume 4, Issue 2, 2015

URL: http://jedep.spiruharet.ro

e-mail: office jedep@spiruharet.ro

\begin{tabular}{|l|l|l|l|l|l|}
\hline Problems & Unimportant & & & & \\
\hline 1.Population Growth & & & & & \\
\hline $\begin{array}{l}\text { 2.Unplanned } \\
\text { Urbanization }\end{array}$ & & & & & \\
\hline 3.Industrialization & & & & & \\
\hline 4.Luxury Living Standards & & & & & \\
\hline 5.Climate Changes & & & & & \\
\hline 6.Nuclear Tests & & & & & \\
\hline 7.Wars & & & & & \\
\hline
\end{tabular}

\section{Environmental Costing and Environmental Accounting Concepts}

\subsection{The following judgments express the degree of importance to you please rate from 1 to 5 .}

\begin{tabular}{|c|c|c|c|c|c|}
\hline & 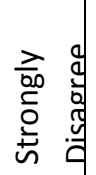 & 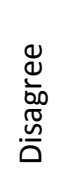 & $\begin{array}{l}\frac{0}{d} \\
\frac{0}{u} \\
\frac{d}{0} \\
\frac{0}{5}\end{array}$ & $\underset{\frac{1}{20}}{\frac{0}{\alpha}}$ & 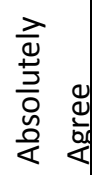 \\
\hline & 1 & 2 & 3 & 4 & 5 \\
\hline $\begin{array}{l}\text { 1. Our business is folded into the various costs on behalf of environmental } \\
\text { protection. }\end{array}$ & & & & & \\
\hline 2. Our businesses, environmentally sensitive policies are followed. & & & & & \\
\hline $\begin{array}{l}\text { 3. Businesses, environmental protection activities related to } R \& D \text { activities, } \\
\text { regular resource allocation is required. }\end{array}$ & & & & & \\
\hline $\begin{array}{l}\text { 4. Studies in the business environment provide the long-term reduction in the } \\
\text { cost. }\end{array}$ & & & & & \\
\hline 5. Our business is committed to protecting the environment for sustainability. & & & & & \\
\hline $\begin{array}{l}\text { 6. Our customers to be environmentally sensitive environmental policies affect } \\
\text { our business. }\end{array}$ & & & & & \\
\hline 7. Environmental issues indicate the status of development of the countries. & & & & & \\
\hline 8. Increased environmental problems affect the future of businesses. & & & & & \\
\hline $\begin{array}{l}\text { 9. Investment decisions retrieving businesses need to consider environmental } \\
\text { sensitivity. }\end{array}$ & & & & & \\
\hline $\begin{array}{l}\text { 10. Enterprises must design their products in such a way that will not harm the } \\
\text { environment. }\end{array}$ & & & & & \\
\hline $\begin{array}{l}\text { 11. Businesses use environmentally friendly products and services, providing } \\
\text { competitive advantage. }\end{array}$ & & & & & \\
\hline $\begin{array}{l}\text { 12. Our business in the production phase of solid, liquid and gaseous wastes are } \\
\text { formed. }\end{array}$ & & & & & \\
\hline 13. Our business activities are carried out on waste management. & & & & & \\
\hline 14. Due to increased environmental problems, the concept of environmental & & & & & \\
\hline
\end{tabular}




\author{
(online) $=$ ISSN $2285-3642$ \\ ISSN-L = 2285 - 3642 \\ Journal of Economic Development, Environment and People \\ Volume 4, Issue 2, 2015 \\ URL: http://jedep.spiruharet.ro \\ e-mail: office jedep@spiruharet.ro
}

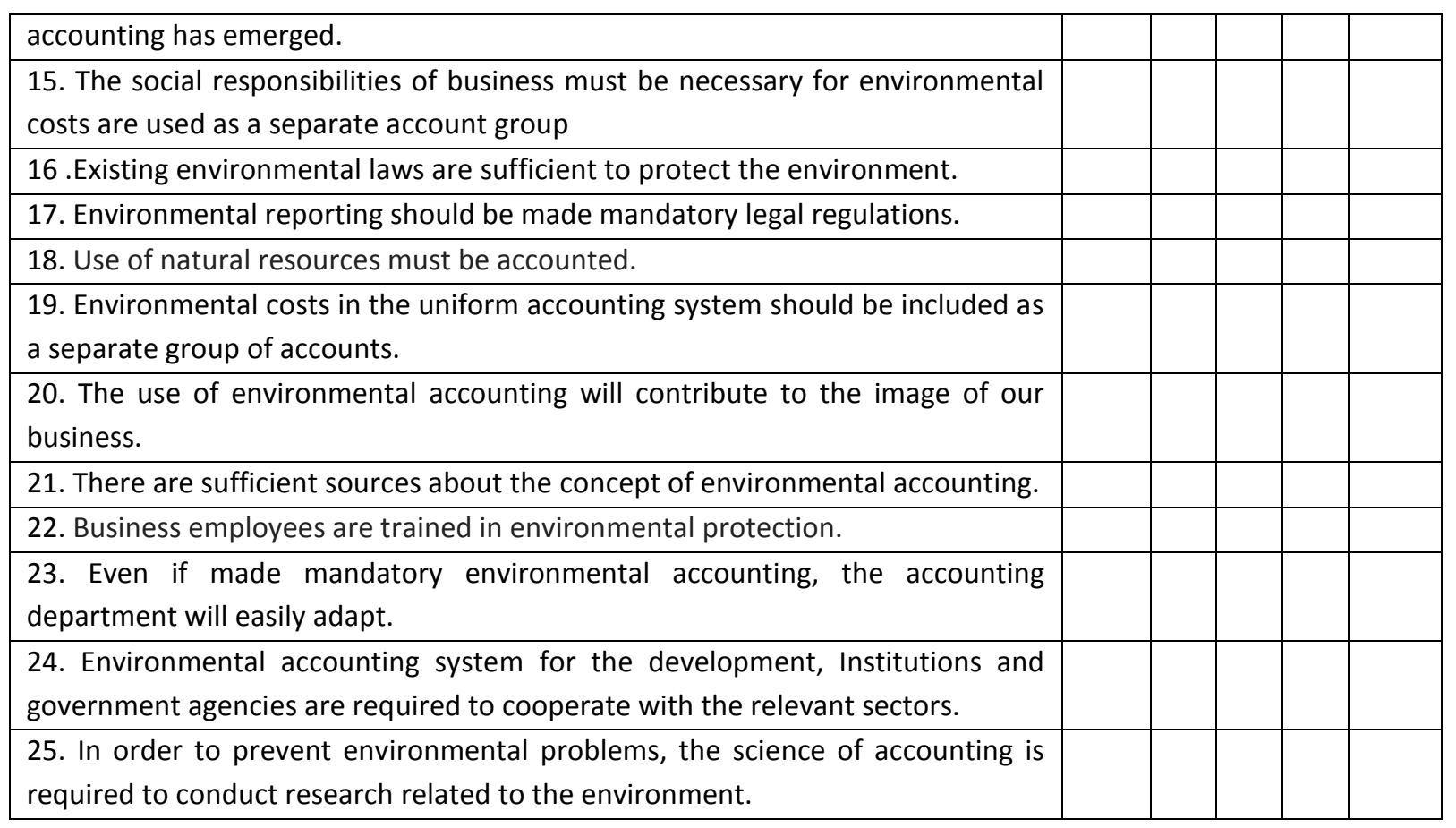

